\title{
Breakthrough in the Development of Vietnamese Business in Order to Grow Rapidly and Sustainably
}

\author{
Quoc Anh Le ${ }^{1^{*}} \quad$ Thi Tram Anh Le ${ }^{2}$ \\ 1.School of Banking \& Finance, National Economics University, \\ ai Phong Road, Hai Ba Trung District, Hanoi, Vietnam \\ 2.University of New South Wales, PO Box 259, Paddington, NSW 2021, Australia
}

\begin{abstract}
In the context of globalization and industrial revolution 4.0 (FIR), it is difficult to develop a national enterprise system to help the economy in the lower middle income group grow fast and sustainably. It is more difficult when that task is carried out in a country whose growth model has not had a solid foundation, to go in the right direction without any "deviation" or "discoloration". It is a breakthrough that must be chosen, with the nature of a "fundamental" stage that needs to be influenced, and this stage in Vietnam has developed significantly. However, it still has many limitations and weaknesses that, for many reasons, have not been overcome not easily. Nevertheless in the face of huge and urgent business development needs, it is possible to base on free trade agreements (FTAs), export commodities, FIR, and real-world fluctuations, to create a breakthrough business development. In particular, it is necessary to renew thinking techniques and developing methods of three business sectors, overcome difficulties, obstacles, exploit and make use of open opportunities to develop businesses. At the same time, it is necessary to ponder and apply deeper Korea's experience, rectify and mitigate risks according to warnings from China's economy and business development practices. Together with focusing on overcoming other indirect obstacles, then the mission of developing business in Vietnam, though very difficult, will be successful and full of hope to contribute much to the prosperity of the country...
\end{abstract}

Keywords: breakthrough, business, deviation, discoloration, prosperity

DOI: $10.7176 / \mathrm{EJBM} / 11-9-19$

Publication date:March $31^{\text {st }} 2019$

\section{Directive ideology and breakthrough phase that must be chosen}

Do not deviate, diverge, but definitely have to innovate - It is the thought that the General Secretary and President Nguyen Phu Trong emphasized when presiding over the first meeting of the Sub-Committee of Documents of the 13th Congress of the Party in the afternoon of January 7th, 2019 in Hanoi. The Congress is expected to be conducted in January 2021, the year celebrating the 35th anniversary of the Doi Moi process, 10 years of the SocioEconomic Development Strategy 2011-2020, towards the 100th anniversary of the establishment of the Party (2030), and 100 years of the founding of the Country (2045). The Congress not only set out the directive tasks of the 2021-2026 term, but also defined the goals towards 2030 and vision towards 2045 . This is meaningful as future orientation, and encouragement for the whole Party, the people, and the army to continue to comprehensively and synchronously promote the renovation process, bringing the country to develop quickly and sustainably, aiming for the goal of wealthy people, strong country, and a democratic, just, and civilized society (Xuan Dan, 2019). That idea shows that, in 10-15 years and about 25 years forward, Vietnam's development strategy is principally a decisive renovation, but "not deviated, diverged". With that changing nature, striving to achieve a gross domestic product (GDP) per capita of 6,500 USD in 2030, increasing to 10,000 USD in the next 5 years, which is 4 times the current number, and becoming a higher middle-income country, is not easy. Because to achieve that ambition, Vietnam needs to achieve a GDP per capita growth rate of about 9.2\% per year during the period of 2019-2035, which is unprecedented, while it seems that the speed is even declining over time, from Doi Moi to the present. 
Table 1. Some major changes of Vietnam's economy in stages, 1991-2018

\begin{tabular}{|c|c|c|c|c|c|c|c|}
\hline \multirow[b]{2}{*}{ Stages } & \multirow[b]{2}{*}{$\begin{array}{c}\text { Average } \\
\text { growth } \\
(\%)\end{array}$} & \multicolumn{6}{|c|}{ Results in the last year of each stage } \\
\hline & & $\begin{array}{l}\text { Number of } \\
\text { operating } \\
\text { businesses }\end{array}$ & $\begin{array}{l}\text { Number of } \\
\text { licensed FDI } \\
\text { projects }\end{array}$ & $\begin{array}{l}\text { Registered } \\
\text { FDI (billion } \\
\text { USD) }\end{array}$ & $\begin{array}{l}\text { Implement } \\
\text { ed FDI } \\
\text { (billion } \\
\text { USD) }\end{array}$ & $\begin{array}{c}\text { Scale of } \\
\text { GDP (billion } \\
\text { USD) }\end{array}$ & $\begin{array}{l}\text { Income } \\
\text { per } \\
\text { capita } \\
\text { (USD) }\end{array}$ \\
\hline 1991-1995 & 8.2 & $24,000^{*}$ & 415 & 7.925 & 2.792 & 20.736 & 250 \\
\hline $1996-2000$ & 7.6 & 39,069 & 391 & 2.762 & 2.398 & 31.173 & 410 \\
\hline $2001-2005$ & 7.34 & 106,616 & 970 & 6.840 & 3.301 & 57.633 & 630 \\
\hline $2006-2010$ & 6.32 & 279,360 & 1,237 & 19.887 & 11.001 & 115.932 & 1,250 \\
\hline 2011-2015 & 5.9 & 442,485 & 2,120 & 24.115 & 14.500 & 193.241 & 1,950 \\
\hline 2016-2017 & 6.51 & 561,064 & 2,741 & 37.101 & 17.500 & 223.864 & 2,170 \\
\hline
\end{tabular}

Source: Word Bank (WB) and General Statistics Office of Vietnam (GSO). Note: (*) Data from 1993 summarized from Communist Party of Vietnam (2007), p. 267-269

To achieve that goal, Vietnam needs drastic changes in many aspects, from awareness, orientation, strategy, policy, apparatus, to operating mechanism and implementing efforts, while at the same time selecting the right "root" phases to create a widespread breakthrough.

\section{The "root" phase of the focus needs to be businesses}

The low income-per-capita level forces our country to see growth as one of the most important socio-economic indicators, but the targets set in the economic framework proposed by the Ministry of Planning and Investment are too high. In order to reach the target that even in the years of "continuous growth", 2005-2010, could not, Vietnam in the coming years needs to have a great impact on many "root" phases, so that from the change of their own and spillover effects, can create a breakthrough for growth. One of the "root" phases that needs special attention, is the enterprise sector, because: (i) Trading in goods and services is the foundation activity that generates, develops social relationships, and is crucial in the formation, survival and development of human society. However, such activities are not spread out evenly, but organized according to each production and business unit, with forms such as private, individual, cooperative, but the most popular and flexible form, sometimes in large and very large units, is businesses. (ii) Thanks to its advantages in gathering and using employees, capital, technology, scientific achievements, integrating utilities, and creating positive externalities, etc., the "corporatization" of the other business practices is an inevitable trend in the market economy (Le Quoc Anh et al., 2018). Its level of expansion is much higher in terms of value, externalities and efficiency in using resources and technology, both helping businesses elevate competitiveness and creating more added value for society. (iii) It is the main source of "players" representing the country in FTAs, therefore, the deeper the integration, the more important it is to develop businesses, to increase the number and quality of "players" in each FTA. This is even more important for the "bottom-up" countries when participating in new-generation FTAs, and more urgent in 2-3 years around the time when FTAs come into effect since it determines the level of success of the integration. (iv) It is the phase that can absorb more and quickly the achievements of the FIR to innovate technology, take the lead and benefit from "latecomer advantage" to create a breakthrough in quality development. In particular, it may be possible to invest in new businesses, increase or upgrade some others, on the other hand, it is possible to increase internal strength, as well as competitiveness for the industry, the sector or the economy. (v) The FDI enterprise sector is an important additional source of external forces, especially in areas that have not yet been developed domestically, thereby creating a spillover effect, bringing capital, technology, and advanced management method to the country to support domestic businesses. The contribution of enterprises in budget revenue and GDP is also increasing, compensating for the decreasing revenue from mining, export and import because of resource exhaustion and tax exemption under FTAs, etc. (Le Quoc Anh \& Le Thi Tram Anh, 2018b). Therefore, every country in the current period considers the enterprise system as the center of the economy, and pays attention to developing enterprises, but how to develop them must firstly be based on the actual state of the current enterprise system...

\section{Vietnam's enterprise system has developed significantly}

Since the 1986 Doi Moi, Vietnam's enterprise system has gradually developed, having four business development climax corresponding with four issuance and amendments of the Enterprise Law (1990, 1999, 2005 and 2014). As a result, the number of operating businesses has increased rapidly (Table 1), which is even more evident in the 2011-2018 period. 
Table 2. State of business development in Vietnam, 2011-2018

\begin{tabular}{|l|r|r|r|r|r|}
\hline & \multicolumn{1}{|c|}{2011} & \multicolumn{1}{|c|}{2013} & \multicolumn{1}{c|}{2015} & \multicolumn{1}{c|}{2017} & \multicolumn{1}{c|}{2018} \\
\hline Number of newly established enterprises & 77,548 & 76,955 & 94,754 & 126,859 & 131,275 \\
\hline Number of out-of-business enterprises & 54,198 & 60,737 & 80,858 & 60,553 & 90,651 \\
\hline Number of operating enterprises & 325,000 & 373,000 & 442,000 & 561,000 & 635,000 \\
\hline
\end{tabular}

Source: $V C C I$ and $G S O$

By 2016, Vietnam has had a relatively sophisticated enterprise system, the number of state-owned enterprises was gradually decreasing according to the equitization and reorganization roadmap; in contrast, the number of non-state enterprises, as well as the number of FDI enterprises, increased much more compared to the previous periods.

Table 3. Vietnamese enterprises according to labor size and form of ownership in 2016

\begin{tabular}{|l|r|r|r|r|r|}
\hline \multirow{2}{*}{ According to labor size } & \multicolumn{3}{|c|}{ Form of ownership } & \multirow{2}{*}{ Total } & \multicolumn{1}{c|}{$\begin{array}{c}\text { Percentage } \\
\text { (\%) }\end{array}$} \\
\cline { 2 - 4 } & $\begin{array}{c}\text { State-owned } \\
\text { enterprises }\end{array}$ & $\begin{array}{c}\text { Non-state } \\
\text { enterprises }\end{array}$ & $\begin{array}{c}\text { FDI } \\
\text { enterprises }\end{array}$ & & 74.04 \\
\hline Micro-enterprises & 77 & 369,847 & 4,017 & 373,941 & 22.43 \\
\hline Small enterprises & 1,029 & 105,982 & 6,278 & 113,289 & 1.63 \\
\hline Medium enterprises & 412 & 6,702 & 1,091 & 8,205 & 1.90 \\
\hline Large enterprises & 1,145 & 5,857 & 2,630 & 9,632 & 100.00 \\
\hline Total & 2,663 & 488,388 & 14,016 & 505,067 & \\
\hline
\end{tabular}

Source: $V C C I$

In general, during the 2007-2017 period, Vietnam's enterprise system developed steadily, with 928,875 newly registered enterprises, bringing the number of registered enterprises to 1,178,010 enterprises. The number of operating enterprises increased by 3.8 times, increasing the number of employees working in enterprises from 7.2 million to over 14 million; total capital in enterprises increased from VND 4.8 million to VND 30.187 million in 2016; Total revenue of the business sector increased from VND 3.5 million to VND 17.449 million (VCCI, 2018, pp. 38-42). In the enterprise system, business regions and sections that are structured according to types, forms of ownership, business lines and territories, have experienced many positive changes. The quality of enterprises in general, and the capacity of each enterprise in particular, based on efficiency of labor usage, solvency, and efficiency of capital use, are increasing steadily. Currently, the business sector contributes $40 \%$ of GDP, 30\% of the state budget, provides over $50 \%$ of the number of jobs for society, and is a reliable support for our country in international integration as well as in the FIR (Le Quoc Anh \& Le Thi Tram Anh, 2018c). Moreover, the higher growth results in the last two years of 2017-2018, which is completely different from the decreasing growth trend of a 10-year cycle, are due greatly to the contribution of the development of enterprises, especially of private enterprises (Le Quoc Anh \& Le Thi Tram Anh, 2018d).

\section{Vietnam's enterprise system still has many limitations, weaknesses}

However, with more than 30 years of transformation - equivalent to the period in which Japan, South Korea, and Singapore transformed from impoverished countries to great powers, it is clear that Vietnam's enterprise system has developed too slowly. It is full of limitations and weaknesses, typically: (i) The enterprise system has gradually increased in volume, but not yet strong, with a large and still increasing number of micro-enterprises, so few businesses are large enough to integrate, and there are even fewer medium enterprises. Every year, the number of newly established enterprises increases, but the number of enterprises that stop operating is still high, in 2014, it was equal to $90.62 \%$ of that of newly established enterprises, thus, the number of operating enterprises increases slowly and remains small. Most businesses are not high in management, capital capacity and competition, using outdated technology, dependent on imported materials and equipment, and using manual labor or simple assembly. (ii) The enterprise sectors according to forms of ownership all have many shortcomings: state-owned enterprises enjoy many privileges and use much capital, yet having inefficient administration, and are difficult to supervise; potential risks arise due to debt, loss and immorality. Non-state enterprises are usually small-scaled with low capital and technology, inexperienced, having limited access to information and market, lacking support, many businesses are at risk of collapse. FDI enterprises use low technology, mainly focus on exploiting cheap labor, causing environmental pollution, having low levels of technology and governance spillover, limited societal contributions, and are demanding of tax exemptions. (iii) The structure of the enterprise system according to fields of activity is unjustifiable, the number of enterprises in agriculture is only about 3,500 enterprises, accounting for $0.87 \%$ of the number of operating enterprises; while $68 \%$ of businesses operate in the service sector, most are small vendors (VCCI, 2017, pp. 36-37). The structure of enterprises according to territory is unbalanced, with most enterprises concentrated in Ho Chi Minh City and Hanoi, accounting for $33.6 \%$ and $23.1 \%$ of enterprises respectively; while the Central Highlands, Mountainous and Northern Midlands regions account for 2.5\% and 3.8\% 
of enterprises respectively (VCCI, 2017, p. 38). (iv) There has not been fair treatment among business sectors to the extent that, for example, a state-owned enterprise is compared to "kindred", while FDI enterprises are "adopted children" and non-state enterprises are "stepchildren"; even though the contribution of "kindred" and "adopted children" has not been commensurate with their preferential advantages. Most businesses have low competitiveness, a lack of development direction, stagnation, low business efficiency, and a lot of potential risks. These limitations make the economy develop below its potential, making it difficult for our country to rise above, and close the gap with great economic powers.

\section{The causes of limitations and shortcomings in developing Vietnamese enterprises}

Firstly, due to the instability of the 1975-1995 period: Vietnam's economy was severely devastated in the Southern liberation war and was subsequently pushed into stagnation by the hasty measurements taken and other psychological factors, while non-socialist economic components are banned. Many major changes pushed Vietnam deeper into the risk of state bankruptcy in 1993, threatened to become a failed country, when foreign debt was nearly $150 \%$ of GDP, and the obligation to repay foreign debt amounted to $195.8 \%$ of total export turnover (Hoang Thi Nang Hong, 2013). The US embargo, Vietnam-China dispute, and the dissolution of the Soviet Union made the infrastructure of our country even more exhausted, and the Vietnam's enterprise system, which is inherently weak, more fragile.

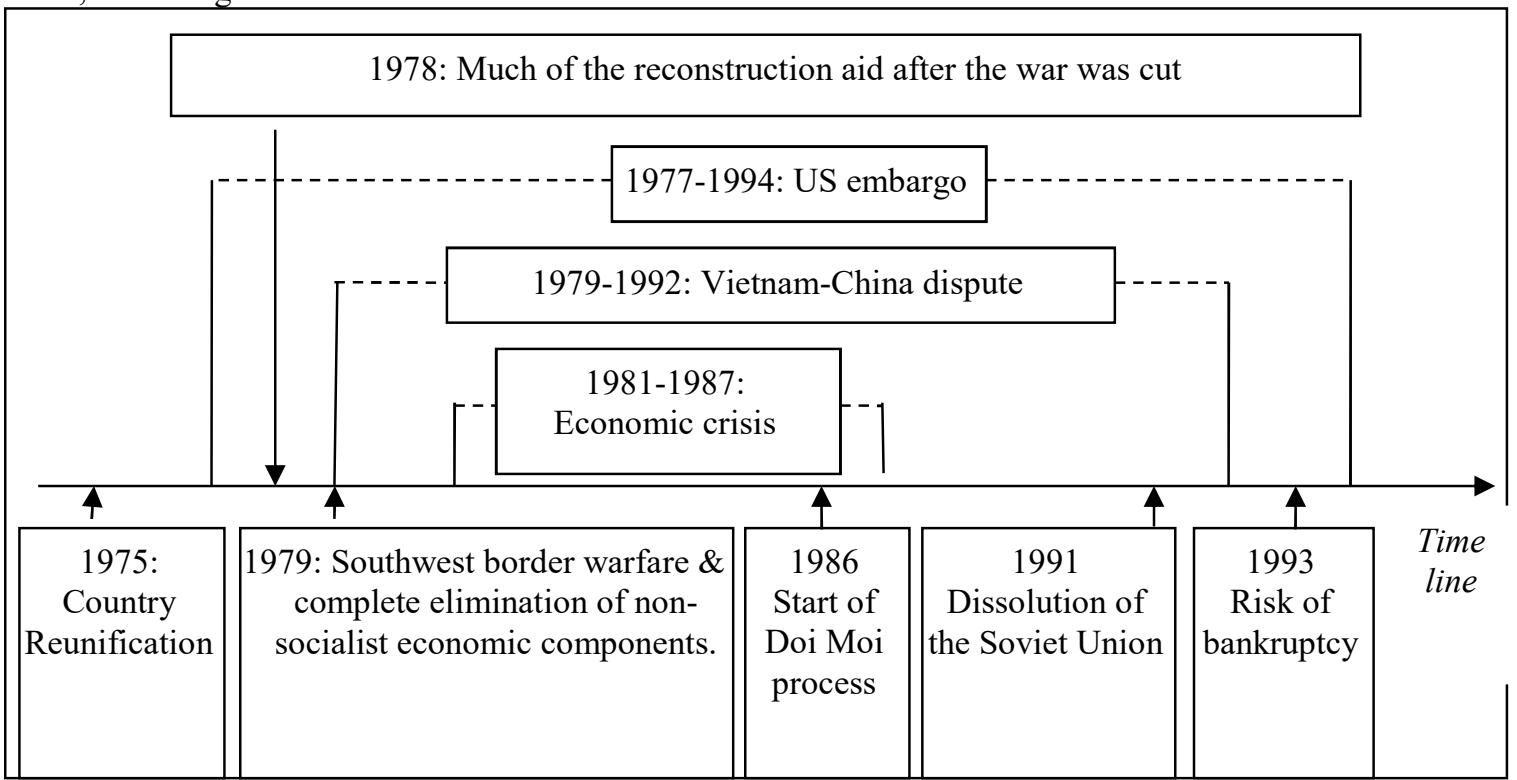

Figure 1. Miserable development context of Vietnamese enterprises, 1975-1994

Many other causes directly affect business development, such as: (i) Misperception in the years previous of 1986 Doi Moi, when Vietnam suppressed all market relations (Vo Nguyen Giap, cited in Dang Phong, 2012, p. 159), seeing market principles as wild thinking (Le Van Tan, cited in Dang Phong, 2012, p. 293), and deploying non-economic models, which were unacceptable (Truong Chinh, cited in Dang Phong, 2012, p. 271). Social criticism had not been properly focused, many dogmatic conceptions existed, the "ask-give" mechanism was not abolished, leading to the violation of market principles, distorting the investment and business environment, and pressing the development of non-state enterprises. (ii) Awareness of enterprises has not kept up with reality: even the document of the $12^{\text {th }}$ Congress has not seen the enterprise system as the center of the economy, whereas the view that enterprise development is the key to new social development is only proposed by the Government. Our country has always followed a general development orientation, while struggling to find a clear direction, and fearing "deviation" and "divergence", thus it is both slow and distressing, making the results low and not solid. (iii) Lack of business development orientation at all three levels, from enterprises, business community, to country; many business owners have limited expertise level, the "envelope" culture distorts the market economy, and business structures have to endure spontaneous changes. The state has not yet accepted civil society, so it is difficult to harmonize the interests between "business-community-state", many "internal" norms make Vietnamese enterprises' thinking low and different, difficult to integrate internationally. (iv) The implementation of enterprise development is arbitrary in all three business sectors, decentralization has no appropriate monitoring mechanism, policy changes are frequent, and plans to "untie" businesses are slow and lacking coordination among ministries and localities. There are many kinds of unreasonable fees, and "lubrication costs" are as high as profits, causing many enterprises to do business temporarily and arbitrarily to survive, unable to expand. (v) There are subjective factors that distort business development activities: the economic model does not have a solid basis, the 
management apparatus keeps the same structure and functions as the subsidy period, and innovation does not keep up with the changes of the economy. There are still many degenerate officials, whilst the mechanism of explanation and accountability is unclear, bribery and corruption prevail, discipline and social morality degrade, whereas government policies are meant for coping, and there are prolonged violations, etc.

\section{The need for business development in our country is strong and urgent}

Demonstrated: (i) On June 3, 2017, Party's Resolution No. 10-NQ/TW on private economic development identified: Striving to have at least 1 million businesses by 2020; by 2025 there should be more than 1.5 million businesses and by 2030, at least 2 million businesses. This is a very high target, because at that time Vietnam had only about 538,000 businesses; 2018 is the year in which the number of enterprises that are newly registered, returning to operations, and increasing their activities all set new records, but the number only increased by about 84,000 businesses. Therefore, the task of developing businesses to achieve the targets set by the Resolution in the next 2 years, as well as in the roadmap to 2025 and 2030, is challenging. (ii) The number of operating enterprises is at a low level, with only 53 in 2016 and 58 in the end of 2018 on average per 10,000 people, which is too low compared to other countries, and is less than 7\% of that of the US in 2010. The weakness of this "root" phrase makes labor productivity in our country frequently one of the lowest in the Asia-Pacific region, leading to an increasing risk of suffering disadvantages in the ASEAN Economic Community (AEC).

Table 4. Some aspects of small and medium enterprises (SMEs), and the average number of businesses per 10,000 people in some countries

\begin{tabular}{|l|r|r|r|r|r|r|r|r|}
\hline & \multicolumn{4}{|c|}{2017} & \multicolumn{3}{c|}{ SME } & \multicolumn{2}{c|}{ At the same time } \\
\cline { 2 - 9 } Country & $\begin{array}{c}\text { Area } \\
\text { (thousand } \\
\mathrm{km}^{2} \text { ) }\end{array}$ & $\begin{array}{c}\text { Population } \\
\text { (million } \\
\text { people) }\end{array}$ & $\begin{array}{c}\text { Average } \\
\text { GNI } \\
\text { (USD) }\end{array}$ & Year & $\begin{array}{c}\text { Total } \\
\text { (thousand } \\
\text { businesses) }\end{array}$ & $\begin{array}{c}\text { of } \\
\text { businesses }\end{array}$ & $\begin{array}{c}\text { Maximum } \\
\text { labor size }\end{array}$ & $\begin{array}{c}\text { Number of } \\
\text { enterprises } \\
\text { per } 10,000 \\
\text { people }\end{array}$ \\
\hline USA & $9,363.4$ & 324.6 & 58,270 & 2010 & $27,827.9$ & 99.94 & $<100$ & 858 \\
\hline China & $9,572.9$ & $1,409.7$ & 8,690 & 2013 & $56,061.6$ & $>99$ & $\leq 50$ & 402 \\
\hline Japan & 377.9 & 127.5 & 38,550 & 2006 & $5,706.0$ & 99.81 & $<250$ & 448 \\
\hline Korea & 100.2 & 50.9 & 28,380 & 2012 & $3,599.2$ & 99.91 & $<250$ & 708 \\
\hline Thailand & 513.1 & 69.0 & 5,960 & 2011 & $2,646.5$ & 99.76 & & - \\
\hline Vietnam & 331.2 & 93.7 & 2,170 & 2016 & 495.4 & 98.09 & $\leq 200$ & 384 \\
\hline
\end{tabular}

Source: WB, SME Finance Forum and VCCI. The maximum of SME labor size in the US and Vietnam is divided by sector; exclusively in Thailand, SMEs are those whose revenue is less than 200 million Baht

(iii) Not only is Vietnam an economy with the highest openness level in the world, with up to 203\% in 2018, it is also a country with intensive economic integration internationally, having either signed or completed 13 out of 17 pursued FTA negotiations. In which, the Comprehensive and Progressive Agreement for Trans-Pacific Partnership (CPTPP) has just come into effect, and the Vietnam-EU FTA (EVFTA) is waiting for approval, both have very high commitments, as well as great benefits if in compliance with the rules of origin. This makes the urgent development of support industry for textile, leather, and electronics industries, etc., a key factor for Vietnam to have a high level of success, avoid being a "low-lying area" of consumption for more than 50 partner countries. (iv) Most Vietnamese enterprises are at a technology level of 2.0 or lower, so promoting the development of enterprises can benefit from "latecomer advantage", creating a turning point in technology, and making leaps of development under the impact of the FIR. Timely transformation is needed for the textile industry, as in 2017 there were 5,213 enterprises, employing 2.5 million workers ( $80 \%$ of which are female), providing 26.04 billion USD of export goods; it is also important for the leather and footwear industry with nearly 1,700 businesses, more than 1.1 million workers and $\$ 16.2$ billion -that are threatened by industrial robots 4.0. Business development also reduces the threat of the FIR to more than 300,000 businesses operating in retail, and more than 383,000 micro businesses that are at risk of more fierce competition (Le Quoc Anh \& Tran Hoai Thanh, 2018). (v) Business development can create a positive effect to strengthen "health" for more than half of those businesses that either have not made profits or are "in fragments" (Vo Tri Thanh, cited in Nguyen Hoai, 2016). It can also provide new businesses to support agriculture, increasing the level of commercialization for agricultural products, and assisting rural development, paving the way for attracting FDI into agriculture. Furthermore, new technologies and jobs can be brought to remote areas, contributing to the completion of industrialization, economic transformation and restructuring of the country. Business development also contributes to the effort of avoiding low-value processing and assembling traps, "polluting paradise" traps, middle-income traps, quickly surpassing the lower middleincome group, and gradually enhancing development.

\section{The goal of business development will not be achievable without breakthroughs}

Without breakthroughs: (i) Human resources will be too scarce for start-ups, because the current education and 
training cannot help nearly 20 thousand people every year who are interested in doing business, and who have enough capital, knowledge, and experience to become new business owners. Human resources graduated from schools need to be retrained to be employed, which make them unsuitable as labor for micro enterprises and small businesses - the most suitable place for business development today. Moreover, as average income is still low, the number of people with enough capital accumulation and ability to invest in business each year does not show much growth, therefore, how to make a qualified person, who has yet to invest, now ready to do business is an important direction for business development. (ii) There is not enough capital to develop enterprises, so on the one hand, it is necessary to attract more FDI, which is part of the structure of the implemented investment capital, that is "poured" into enterprise development. On the other hand, it is also necessary to minimize the part of "fasting for public investment" of the state economic sector (Bao Anh, 2011), shift to developing support industries; and encourage the private sector to invest in establishing businesses - because these two sources have not been well capitalized for businesses. It is important to promote the development of funds related to businesses, and help young intellectuals access those funds, as well as credit capital, to promote the entrepreneurial movement of individuals and groups of graduates who are unemployed.

Table 5. Investment capital for development of the whole society by economic class

\begin{tabular}{|c|r|r|r|r|r|r|r|}
\hline \multirow{2}{*}{ Year } & \multicolumn{4}{|c|}{$\begin{array}{c}\text { Investment capital for development of society } \\
\text { (billion VND) }\end{array}$} & \multicolumn{3}{c|}{$\begin{array}{c}\text { Percentage } \\
(\%)\end{array}$} \\
\cline { 2 - 8 } & Total & $\begin{array}{c}\text { State } \\
\text { economy }\end{array}$ & $\begin{array}{c}\text { Non-state } \\
\text { economy }\end{array}$ & FDI sector & $\begin{array}{c}\text { State } \\
\text { economy }\end{array}$ & $\begin{array}{c}\text { Non-state } \\
\text { economy }\end{array}$ & $\begin{array}{c}\text { FDI } \\
\text { sector }\end{array}$ \\
\hline 1997 & 108,370 & 53,570 & 24,500 & 30,300 & 49.4 & 22.6 & 28.0 \\
\hline 2002 & 200,145 & 114,738 & 50,612 & 34,795 & 57.3 & 25.3 & 17.4 \\
\hline 2007 & 532,093 & 197,989 & 204,705 & 129,399 & 37.2 & 38.5 & 24.3 \\
\hline 2012 & $1,010,114$ & 406,514 & 385,027 & 218,573 & 40.3 & 38.1 & 21.6 \\
\hline 2017 & $1,668,601$ & 594,885 & 677,510 & 396,206 & 35.7 & 40.6 & 23.7 \\
\hline
\end{tabular}

Source: GSO

(iii) Sustainable and effective development of enterprises faces difficulties, if they do not have "land" on which to operate, or are bound by institutions, hindered by unfair competition, high cost of capital, and support that is too little or impractical, yet is heavily mobilized, as well as having large "lubrication" costs, etc. Failure to improve that situation cannot reduce the number of businesses that have to stop operation, thus making the number of businesses operating in difficulty increase rapidly, causing waste or loss of social resources. Numbers such as: $32 \%$ of operating micro-enterprises incurred financial losses in 2018 (Hieu Cong, 2018), 90\% of start-ups make no profits in the first 3 years, 95\% of businesses fail after 5 years of start-up (Thai Phuong, 2018), make it easy to turn young entrepreneurs' aspirations into nightmares. (iv) The start-up movement is likely to break out and disappear quickly, letting fear lurk behind the dream of becoming "the boss", changing the life of thousands, when the state does not utilize its administrative function in order to enhance the country's business culture. The state must not let the capital margins, which are already very small in relation to the global competition, be eliminated in the competition between domestic enterprises, and let interests be capitalized by foreigners. Therefore, it should give more authority to genuine associations, and bestow upon them democracy and total authority in creating winwin relationships, in order to quickly raise the level of enterprises that are about to gain investment. (v) It is completely meaningless, if businesses' lifespan is short because their investments are "misdirected" and "inappropriate", or even become expensive and obscure "life lessons" for a country that is still poor. It is even more pointless when the benefiting industries mainly fall into the hands of foreign investors, while a series of other industries receive worsened treatment because of the Government's "ugly concessions". Therefore, the state should "release" enterprises wisely so that the economy can raise its competitiveness in integration, avoid falling behind in the FIR, while striving to develop and nurture revenue sources, in order to accomplish the goal of developing businesses actively and positively.

\section{The necessary foundation for breakthroughs in business development}

Rapid and sustainable growth needs great and comprehensive efforts of all ministries, sectors, localities, reflected in solutions that incorporate scientific breakthrough, and in innovative and practical transformations. In order to avoid obstinate, delusional, hasty or subjective thinking when making breakthroughs in business development, Vietnam should decide on: (i) Recent and upcoming FTAs: even though each FTA poses many challenges for some industrial sectors because of the state's "ugly concessions", it also brings about many opportunities for market expansion in today's context of supply always exceeding demand. The current golden opportunity is the three FTAs that have just come into effect, which are: the Vietnam-Korea FTA (VKFTA), the Vietnam FTAEurasian Economic Union (VCUFTA), and the CPTPP. In addition, there is the EVFTA that is waiting for approval, the Regional Comprehensive Economic Partnership Agreement (RCEP) whose negotiations has just been completed, and the process of integrating with the AEC region in the form of a new "underground" FTA (Le Quoc Anh, 2017a). 
Table 6. Viet Nam's recent and upcoming FTAs

\begin{tabular}{|c|c|c|c|c|c|c|c|c|c|}
\hline \multirow[t]{2}{*}{ FTA } & \multirow{2}{*}{$\begin{array}{l}\text { Number } \\
\text { of } \\
\text { members }\end{array}$} & \multirow{2}{*}{$\begin{array}{l}\text { Fields } \\
\text { of } \\
\text { commit- } \\
\text { ment }\end{array}$} & \multirow{2}{*}{$\begin{array}{l}\text { Effect- } \\
\text { ive } \\
\text { date }\end{array}$} & \multirow{2}{*}{$\begin{array}{c}\text { Popula- } \\
\text { tion } \\
\text { (million } \\
\text { people) }\end{array}$} & \multirow{2}{*}{$\begin{array}{l}\text { GDP } 2017 \\
\text { (billion } \\
\text { USD) }\end{array}$} & \multicolumn{3}{|c|}{$\begin{array}{c}\text { Relative to region (tỷ } \\
\text { USD) }\end{array}$} & \multirow{2}{*}{$\begin{array}{l}\text { Eliminat- } \\
\text { ing } \% \text { of } \\
\text { tariff }\end{array}$} \\
\hline & & & & & & Time & $\begin{array}{l}\text { Ex- } \\
\text { port }\end{array}$ & $\begin{array}{l}\text { Im- } \\
\text { port }\end{array}$ & \\
\hline VKFTA & 02 & 17 & 2016 & 150 & 1,720 & 2017 & 15.0 & 46.8 & 95.44 \\
\hline VCUFTA & 06 & 15 & 2016 & 280 & 2,200 & 2016 & 1.77 & 1.27 & $\approx 90$ \\
\hline EVFTA & 29 & 21 &.. & 500 & 15,000 & 2017 & 41.1 & 9.3 & 99.20 \\
\hline СРТРP & 11 & 30 & 2019 & 495 & 10,200 & 2015 & 29.6 & 29.1 & $\approx 100$ \\
\hline RCEP & 16 & .. & .. & 3.400 & 21,000 & 2017 & $\approx 100$ & $\approx 150$ & $\approx 80$ \\
\hline
\end{tabular}

(ii) Both primary and expected exports: as the recently effective FTAs have doubled the possibility of developing these products by reducing taxes and dismissing many competitors that are of non-participating countries in the respective FTAs. In which, Vietnamese garment, footwear and seafood products will be reduced by more than $7 \%$ of taxes, thus becoming an attractive supplier that can substitute for Chinese, Indian, Bangladesh, Indonesian, etc., products. This provides business development opportunities in these sectors and their support industries in order to comply with rules of origin, as well as open great prospects for exporting tropical flowers and vegetables. (iii) The FIR while threatens many industries because it brings about the ability to automate with quick and convenient linkage, it also opens great prospect for developing businesses that benefit from the new technology. The FIR can help develop SMEs to bring together separate capabilities, such as specialty plants and animals, traditional goods, and tourism resources suitable for exploitation, and link them to form new key products. It also creates conditions to help agricultural enterprises shift to developing exports qualified for difficult markets, such as the US, EU and Japan, thus helping Vietnamese businesses penetrate global value chains. (iv) Unused and disconnected areas in the enterprise system: as it is difficult to raise the standard of living if people do not produce goods, and hard to compete without optimizing the production process. In order to increase success in integration, Vietnam needs to promote the development of enterprises in agricultural areas, rural areas, mountainous areas and islands, where many communes have less than one to two businesses. The state also needs to quickly supplement the weak and missing stages in the business clusters, zones and sectors, to compensate for the lack of attention paid to develop the win-win business culture in the past. (v) Volatility in the economic and commercial part of the world: through which Vietnam can gain more production and consumption partners, and opportunities to enter new markets. This direction is very promising, when the US-China trade war is increasingly complicated and showing no signs of closure in the near future. The incidents of Huawei Telecommunications Group have caused problems to the Chinese reputation, thus creating opportunities for Vietnamese businesses to rise and overcome the "shadow" of China in global trade.

\section{Innovation of thinking and methods of developing state-owned enterprises}

The term "state-owned enterprise" used here is not identical to the term "state-owned enterprise" as explained in the Enterprise Law 2014 (Law No. 68/2014/QH13), which defines state-owned enterprises as enterprises with 100\% charter capital owned by the state. It refers to all enterprises that the state controls, that is, including both conventional state-owned enterprises and enterprises that the state holds the dominant power - according to the understanding of business managers in Vietnam. From that point of view, the state-owned enterprise sector: (i) From accounting for all 12,000 Vietnamese enterprises in 1986, after undergoing the process of reorganization and equitization since 1992, the number of state-owned enterprises has decreased gradually, by 2017 there were only 2,663 enterprises: in which there were 652 conventional state-owned enterprises, including 9 corporations and 65 groups of general companies. In general, state-owned enterprises are gradually more appropriately restructured, with $43.0 \%$ being large enterprises, focusing on key sectors and industries of the economy; the number of state-owned enterprises operating with profits in the past few years is often over $80 \%$. The sector providing essential public goods and services for society and national defense and security is still a key business area of our country. (ii) State-owned enterprises are also considered "superficial" enterprises, managed by many venues and run termly by administrative decisions and legal framework that are incomplete, thus having many shortcomings in the implementation and monitoring mechanism. They control many areas of business that the private sector can do, even though the pace of planned divestment is slow, there is confusion between management and business functions, and efficiency is low. Many state-owned enterprises have dubious rights to dominate the operation, not complying with the stock exchange, carrying many potential risks, to the extent of being considered a "terrible burden" of the economy (Le Kien Thanh, 2017). (iii) State-owned enterprises are also subjected to an excess of important responsibilities in the market economy, often prioritized above the necessary level, resulting in distortion in competition and warping market signals. Self-discipline in business activities is sometimes not properly complied with when many state-owned enterprises invest outside their core values, targeting sensitive sectors such as banks and real estate. Many of which have high bank loans, an abundant of bad debts, many 
inventories, and rigidity in product structure, although the proportion of businesses operating with profits is accelerating, up to $97 \%$ in 2017 , actual profit is often small. (iv) It is necessary to change to thinking in accordance with international practices of state-owned enterprises, from internal functions, functions, governance, to scope of business, incentives, and social responsibility. Continue to restructure, innovate and improve efficiency, maximize divestments in state-owned enterprises that are "encroaching" on private enterprises, shifting them to developing industrial support or helping businesses in the conversion process. When required state-owned enterprises should only be allowed to make "bait" investment, then quickly withdraw to make room for the private sector, thus minimizing non-economic interventions, so that only conventional state-owned enterprises remain. (v) The State must gradually abandon its production function, carry out "businessization" of leaders of state-owned enterprises, and hire directors for state-owned enterprises that have not divested in time. It is necessary to return noncompulsory fields to the private economy, enhance operational transparency and accountability, and in novate the evaluation process of the performance of state-owned enterprises. Implement "strategic audits" to clarify costbenefit correlations, including hidden costs - such as "holding costs", "time costs", and "sunk costs" (Shlomo Maital, 2015, p. 71-87), that are generally unfair and heavily exploited by weak state-owned enterprises.

\section{Renovating thinking and methods of developing domestic non-state enterprises}

The non-state enterprise sector in Vietnam: (i) Had a rapid development in quantity, from a prohibited component before Doi Moi 1986 to totaling 6,806 enterprises in 1993, quickly increasing to 35,004 enterprises in 2000, and then to 147,316 enterprises in 2007. By the end of 2013 it accounted for over 97.5\% of 468,600 active businesses, employing more than half of available social workers and working capital, contributing an increasingly large part in the national enterprise system. By the end of 2018, this sector had more than 1 million registered enterprises, with 629,000 still operating enterprises, accounting for $98.1 \%$ of the total number of operating enterprises, while the 100 largest private enterprises accounted for about 1/4 of Vietnam's GDP. (ii) Had many limitations and weaknesses, such as low capital, low technology, inexperience, insensitivity to grasping information and accessing the market, difficulties in upgrading technology, expanding, and a chronic lack of capital and support. Overspreading and multi sectoral investment and the use of strong financial leverage in the period of 2008-2011 has made the rate of dissolved private enterprises in the years of 2011-2018 high in overall. In 2016, this area was composed of only $1.20 \%$ big enterprises, $1.37 \%$ medium enterprises, and $75.73 \%$ micro enterprises; especially due to low profit margin, this area made very limited contribution to the GDP.

Table 7. Contribution to GDP by economic sector (\%), 2006-2016

\begin{tabular}{|l|r|r|r|r|r|r|}
\hline & \multicolumn{1}{|c|}{2006} & \multicolumn{1}{c|}{2008} & \multicolumn{1}{c|}{2010} & \multicolumn{1}{|c|}{2012} & \multicolumn{1}{|c|}{2014} & \multicolumn{1}{|c|}{2016} \\
\hline State economy & 37.6 & 35.1 & 33.6 & 32.6 & 31.9 & 32.0 \\
\hline Community economy & 6.4 & 5.9 & 4.6 & 4.4 & 4.5 & 4.4 \\
\hline Individual economy & 31.9 & 31.4 & 36.7 & 36.3 & 35.0 & 33.8 \\
\hline Private economy & 9.0 & 10.2 & 7.9 & 8.8 & 8.7 & 9.1 \\
\hline FDI economy & 16.1 & 17.4 & 17.3 & 17.8 & 19.9 & 20.7 \\
\hline
\end{tabular}

Source: Tu Giang (2018)

(iii) The reason is that enterprises are slow to be recognized as the center of the economy, and the state has yet to see the role of private enterprises, focusing only on the number of enterprises. The business development environment still has many boundaries, the market system is not synchronous and transparent, and the capacity of many enterprises is unstable, with low profitability and dependent on the high mobilization of state capital. Incentives for business development are leveled off, monopolistically for state-owned enterprises, and excessively for FDI enterprises, sometimes even arbitrarily. (iv) The advantages for the development of domestic non-state enterprises are currently enormous, when the Party has just issued a Resolution on private economic development, the SME Support Law has just been passed by the National Assembly, and the Government takes "accompanying with business" as a guideline for operation. The Prime Minister has set up an SME Development Advisory Group, focusing on meeting businesses, promoting the role of the Vietnam Chamber of Commerce and Industry (VCCI), as well as the SME Association, in development orientation. At the same time, promote reviewing and streamlining business conditions, reform administrative procedures, suppress "petty" corruption, speed up divestment of state capital, and return "land" for domestic non-state enterprises to work. (v) In order to accelerate the development of domestic non-state enterprises, the state needs to switch to enterprise management, set up business development boards for each sector and region, and transfer associations to substantial operation. Develop business networks to cater for each FTA, transform agricultural cooperatives into business models, give high incentives for businesses shifting from trade and services to production. Abolish the requirement of transaction offices for micro-enterprises, simplify accounting and tax tables for monotonous business enterprises, ad dispose of public officials and servants that are troublesome for enterprise development, etc. 


\section{Renovating thinking and methods of developing FDI enterprises}

Development of FDI enterprises in Vietnam: (i) Has made a lot of achievements, with strong disbursement beginning in 1991 under the impact of the Foreign Investment Law 1987, since then, the number of FDI projects, annual registered capital, and implemented capital, etc. often increased.

Table 8. Number of FDI projects, registered capital and implemented capital, 1988-2017

\begin{tabular}{|l|r|r|r|}
\hline & Number of projects & \multicolumn{1}{|c|}{$\begin{array}{c}\text { Total registered capital } \\
\text { (million USD) }\end{array}$} & $\begin{array}{c}\text { Total implemented capital } \\
\text { (million USD) }\end{array}$ \\
\hline $1988-1991$ & 363 & $2,887.9$ & 428.5 \\
\hline 1992 & 196 & $2,077.6$ & 574.9 \\
\hline 1997 & 349 & $5,955.6$ & $3,277.1$ \\
\hline 2002 & 808 & $2,993.4$ & $2,884.7$ \\
\hline 2007 & 1,544 & $21,348.8$ & $10,034.1$ \\
\hline 2012 & 1,287 & $16,348.0$ & $17,500.0$ \\
\hline 2017 (preliminary) & 2,741 & $37,100.6$ & $\mathbf{1 7 1 , 9 9 2 . 9}$ \\
\hline Cumulative total & $\mathbf{2 6 , 7 4 6}$ & $\mathbf{3 7 8 , 6 9 8 . 7}$ & \\
\hline
\end{tabular}

Source: $G S O$

FDI brings in many leading brands of 129 countries and territories, making Vietnam an important country in exporting phones, computers, electronic products, shoes, garments, and cameras, etc. It creates about $50 \%$ of industrial output value, resulting in high-tech products accounting for nearly $30 \%$ of total export turnover; creating 8 to 9 million direct and indirect jobs, making a major contribution to the 7.2 billion USD of trade surplus in 2018, and becoming one of Vietnam's two main growth engines today.

Table 9. Percentage of contribution of the FDI sector in Vietnam's economy, 2002-2017

\begin{tabular}{|l|r|r|r|r|r|}
\hline Percentage of FDI sector in (\%) & \multicolumn{1}{|c|}{2002} & \multicolumn{1}{|c|}{2007} & \multicolumn{1}{c|}{2012} & \multicolumn{1}{c|}{2016} & 2017 (preliminary) \\
\hline ... Use of social labor & 1.1 & 3.5 & 3.3 & 6.7 & 7.8 \\
\hline ... Total social investment capital & 17.4 & 24.3 & 21.6 & 23.6 & 23.7 \\
\hline ... GDP &.. & 16.9 & 16.0 & 18.6 & 19.6 \\
\hline ... Import turnover & 33.9 & 34.6 & 52.7 & 58.5 & 59.9 \\
\hline ... Export turnover & 47.1 & 57.2 & 63.1 & 71.5 & 72.5 \\
\hline
\end{tabular}

\section{Source: GSO}

(ii) FDI enterprises have many limitations and shortcomings, such as low average capital, often using cheap labor with low skills, no high technology, having low added value and no technological transfers (Vu Quang Viet, 2018). The majority of FDI enterprises are in the industries of processing garments, footwear, and electronic assembly, which makes its economy one that is heavily characterized by low-leveled processing and "export products of other countries"; only a few projects are placed in the fields of agriculture, forestry, fisheries, electricity to create a "push" for breakthroughs. In 2016, there were 4,017 micro FDI enterprises, accounting for 28.66\% of FDI enterprises (VCCI, 2018), that threatens to leave a lot of issues when withdrawn, making the economy heavily dependent on FDI, and if they malfunction, Vietnam would be very vulnerable to risks.

Table 10. Foreign direct investment licensed by economic sector (Accumulated valid projects until December 31, 2017)

\begin{tabular}{|l|r|r|r|r|}
\hline & \multirow{2}{*}{$\begin{array}{c}\text { Number of } \\
\text { projects }\end{array}$} & $\begin{array}{c}\text { Registered capital } \\
\text { (million USD) }\end{array}$ & \multicolumn{2}{|c|}{$\begin{array}{c}\text { Percentage of } \\
(\%)\end{array}$} \\
\cline { 4 - 5 } & & & \multicolumn{1}{c|}{ Project } & \multicolumn{1}{c|}{ Capital } \\
\hline Total & $\mathbf{2 4 , 8 0 3}$ & $\mathbf{3 1 9 , 6 1 3 . 1}$ & $\mathbf{1 0 0 . 0 0}$ & $\mathbf{1 0 0 . 0 0}$ \\
\hline Agriculture, forestry, and fisheries & 511 & $3,521.2$ & 2.06 & 1.10 \\
\hline Manufacturing and processing industry & 12,460 & $186,514.2$ & 50.23 & 58.36 \\
\hline $\begin{array}{l}\text { Production and distribution of electricity, gas } \\
\text { and water }\end{array}$ & 115 & $20,820.9$ & 0.43 & 6.51 \\
\hline Real estate sector & 639 & $53,226.0$ & 2.58 & 16.65 \\
\hline Others & $\mathbf{1 1 , 0 7 8}$ & $\mathbf{5 5 , 5 3 0 . 8}$ & $\mathbf{4 4 . 6 5}$ & $\mathbf{2 7 . 3 8}$ \\
\hline
\end{tabular}

Source: GSO

(iii) Restrictions and shortcomings are caused by the fact that our country has 7-8 years since 1979 completely removing non-socialist economic components, having no formal, focused and drastic FDI attraction strategies. Due to short-sighted vision and the lack of coordination among ministries and localities, FDI often focuses on the easiest and lowest value stage, which makes it difficult to grow, and thus these projects gradually become "professional low value processors" (Vu Thanh Tu Anh, 2018). The limited capacity of managerial staff and corruption make the contribution of the FDI sector inadequate, causing many environmental incidents, pressing private enterprises, bringing the economy closer to economic traps, and facing potential macroeconomic risks. (iv) 
Demand for FDI attraction in Vietnam in the coming period is very large because of slowed growth, which is lower than the growth required to ensure Vietnam overcome the middle-income trap. The amount of remittances is unlikely to increase, the growth pattern slow to change, and the motivation for innovation still low, while public debt is large, with high recurrent spending and increasing debt payment that hinder investment and support of businesses. The FIR came about while most businesses still use technology 2.0, so in order to increase our success in the CPTPP, FDI attraction must be strengthened to protect Vietnam's economy from exposure to risks, however, the obsolete policy of attracting investment must not be continued. (v) Innovation to attract FDI must be in ways that encourage foreign investors via policies and ecosystems that they can be involved in, for example, lessons can be learned from the experience of Israel (Nguyen Hung, 2017). Incentives must be focused, firm, and consistent with prioritized directions; they should be gradually reduced as the size of the prioritized industry increases. From 1 to 2 priority directions must be paid for FTAs that are soon to take effect, focusing on ensuring rules of origin, taking advantage of the market, and using technology 4.0 to attract FDI in stages to create new development directions for Vietnam.

\section{Business development in Vietnam has many difficulties and obstacles}

Typically: (i) The State has yet to locate where the Vietnamese economy is standing on the development roadmap, besides having a "socialist orientation", to point out the next proper and practical step. The non-solid basis, the current way of growth that makes many people richer yet is less beneficial to the community (Bui Trinh, 2014), and the issue that "this year's growth must be higher than the previous year", only deepen the instability, to the point that the economy needs to start over (Nguyen Tran Bat, cited in Cam Thuy, 2014). This is the main reason why Vietnam's enterprises not only lose their opportunities but also are hindered by rigid thinking, not daring to invest strategically, and being sluggish in the half-hearted transformation of the state, deadlocked in the form of "not caring to develop".(ii) "Portions of Vietnamese economic structure" is fragmented (Tran Dinh Thien, 2011), while the financial and monetary market is unfavorable for business development, especially in the context of Vietnam joining many new generation FTAs recently and in the future. The stock market is still weak, while the bank undertakes the majority of capital needs, but with high interest rates, strict borrowing conditions, and difficult mortgage of real estate, Vietnam's enterprises are clearly disadvantaged before foreign businesses. The state has not been able to support business development, with high recurrent spending, paying debts, public debt, and bad debt, high ICOR, while the growth foundation is weak, and infrastructure has yet to develop.

Table 11. Some of Vietnam's financial indicators, 2012-2017

\begin{tabular}{|l|r|r|r|r|r|r|}
\hline & \multicolumn{1}{|c|}{2012} & \multicolumn{1}{|c|}{2013} & \multicolumn{1}{|c|}{2014} & \multicolumn{1}{c|}{2015} & \multicolumn{1}{c|}{2016} & \multicolumn{1}{c|}{2017} \\
\hline Recurrent spending/total budget expenditure & 58.30 & 67.37 & 65.52 & 69.99 & 69.22 & 70.73 \\
\hline State budget overspending (\% of GDP) & 5.36 & 5.45 & 5.70 & 6.10 & 5.05 & 3.42 \\
\hline Average interest from bank (\%) & 13.47 & 9.63 & 8.16 & 6.96 & 6.96 & 7.40 \\
\hline Percentage of public debt (\% of GDP) & 30.8 & 54.2 & 58.0 & 61.2 & 63.6 & 62.6 \\
\hline Percentage of foreign debt (\% of GDP) & 37.4 & 38.3 & 39.9 & 42.0 & n.a & 45.2 \\
\hline Incremental Capital - Output Ratio (ICOR) & 5.9 & 5.6 & 5.2 & 6.9 & 6.4 & 6.1 \\
\hline
\end{tabular}

Source: GSO and WB

(iii) Many innovations and reforms related to enterprises, especially in terms of business conditions, are not yet practical: by the end of 2018,542 business conditions were revised, 771 were repealed, and replaced 111; but there were also 29 new business conditions. The goal of abolishing and simplifying 50\% of the Government's business conditions was not achieved, focusing more on simplify rather than abolish, and the change of management methods is still few and hesitant. Only about $30 \%$ of business regulations were removed or substantially modified, state intervention and "wiser" than the market thinking is still popular, and the role of associations is weak, making the costs high and many business barriers still exist (Huyen Trang, 2018).(iv) The management apparatus is very slow to innovate, although the Party has long identified that "quite a number" of officials and party members has become degenerated, with up to $30 \%$ of civil servants cannot do the job required. However, the number of disciplined and removed officials is few, and there are many cases of insensitivity that "obstructs" businesses, potentially becoming an obstacle, making it difficult to implement policies and inhibiting development (Le Quoc Anh \& Le Thi Tram Anh, 2017). The situation of "passivity between activity" obstructs the innovation movement, resulting in the number of out-of-business enterprises always high in recent years, particularly 2018 set a record with 90,651 enterprises, up $49.7 \%$ compared to the last year.(v) Complex international context, when protectionism is returning, but Vietnam must step up its integration process despite it being a "life-or-death situation" (Nguyen Duc Kien, cited in Tu Giang, 2014). The US-China trade war and the boycott of Huawei are likely to strengthen China's "shadow"; while the "warming-up" of inter-Korean relations will significantly affect the business environment of Vietnam's enterprises. The rapid economic growth of Laos and Cambodia, along with the rapid improvement of democracy in Myanmar, is decreasing Vietnam's attractiveness in the eyes of international investors. 


\section{There are many important open directions for business development in Vietnam}

Compensating for the difficulties and disadvantages, the development of enterprises in Vietnam currently has many open directions, especially the direction that anticipate and benefit from the FTAs, in order to increase the rate of localization to meet rules of origin. On the other hand, with more than 50 partners, in many geographical areas, and a diversified array of development levels, as in CPTPP (table 12), the direction that Vietnam's enterprises should focus on labor-intensive product segment is full of hope, when it helps avoiding China and India. Many businesses can also be developed to improve the "health" and internal strength for the whole system; expand the benefiting industries, improve export capacity, and take advantage of the integrated market.

Table 12. Overview of CPTPP members in 2017

\begin{tabular}{|l|r|r|r|r|r|r|}
\hline Member country & \multicolumn{1}{|c|}{$\begin{array}{c}\text { Area } \\
\left(\mathrm{km}^{2}\right)\end{array}$} & \multirow{2}{*}{$\begin{array}{c}\text { Population } \\
\text { (thousand } \\
\text { people) }\end{array}$} & $\begin{array}{c}\text { GDP } \\
\text { (billion }\end{array}$ & USD) & \multicolumn{3}{|c|}{ Per capita (USD) } \\
\cline { 6 - 8 } & & & & GDP & GDP(PPP) & GNI \\
\hline Singapore & 716 & $5,712.5$ & 323.9 & 57,714 & 85,535 & 54,530 \\
\hline Australia & $7,692,024$ & $24,464.8$ & $1,323.4$ & 53,799 & 44,609 & 51,360 \\
\hline Canada & $9,984,670$ & $36,638.3$ & $1,653.0$ & 45,032 & 44,018 & 42,870 \\
\hline New Zealand & 270,467 & $4,707.8$ & 205.8 & 42,940 & 36,086 & 38,970 \\
\hline Japan & 377,930 & $126,473.4$ & $4,872.1$ & 38,428 & 39,002 & 38,550 \\
\hline Brunei & 5,765 & 428.9 & 12.1 & 18,290 & 71,809 & 29,600 \\
\hline Chile & 756,102 & $18,061.1$ & 277.1 & 15,346 & 22,767 & 13,610 \\
\hline Malaysia & 330,803 & $31,642.7$ & 314.5 & 9,945 & 26,808 & 9,650 \\
\hline Mexico & $1,964,375$ & $129,234.9$ & $1,149.9$ & 8,903 & 17,336 & 8,610 \\
\hline Peru & $1,285,216$ & $32,182.8$ & 211.4 & 6,572 & 12,237 & 5,970 \\
\hline Vietnam & 331,212 & $94,485.5$ & 223.9 & 2,343 & 6,172 & 2,170 \\
\hline
\end{tabular}

Source: WB and Wikipedia

The second direction is to develop businesses that benefit from the FIR, to help develop and improve competitiveness for industries, promote economic restructuring, such as in the fields of information technology and biology. Develop businesses in potential industries that have difficulty in selling products after expansion, such as high-tech agriculture, tropical fruits and vegetables. When correctly done, it is likely to create a boom in business development in the industries that need linkage and support from development partners, strategic partners, or in the industries that aim for sustainable development. The third direction is to develop businesses to serve the Government's efforts, in order to avoid middle-income traps, it is necessary to develop businesses that provide agricultural support and increase commercialization of agricultural products. To avoid cheap labor traps, low-value processing traps, "polluting paradise" traps, from our current position in the first stage in the process of catch-up industrialization, it is vital to wisely attract FDI, develop new and practical businesses. Develop competent businesses to help complete the unfinished process of industrialization after more than 50 years, complete economic transformation after more than 30 years, and support business restructuring (Le Quoc Anh \& Le Thi Tram Anh, 2018a). 


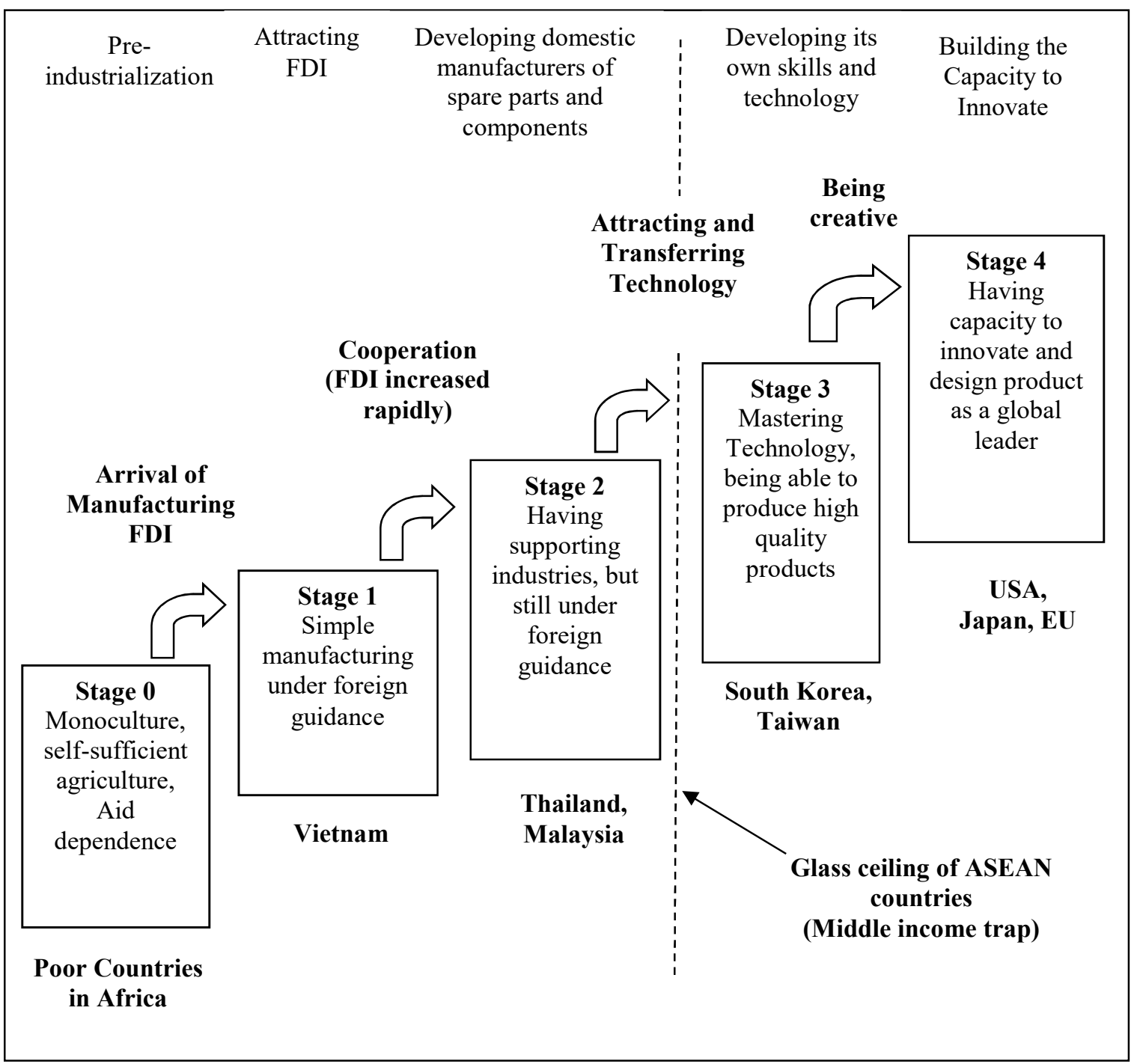

Figure 2. Main stages of Catch-Up Industrialization

Source: Kenichi Ohno (2010)

Applying international recommendations is also an important business development direction, such as the suggestion from EuroCham that Vietnam should become a producer of cars and electric scooters (An Lan, 2016); from World Bank that local suppliers should be developed to meet quality standards in the global value chain (WB, 2016). Divide resources for businesses regardless of size, type, ownership according to audit results as proposed by Dapice et al. (2006); build "pillars" for the supporting industries development roadmap as proposed by WB (2017). Or take advantage of the growth wave to diversify and rise to participate in higher value stages; continue to reform and support the development of the private economic sector as proposed by the International Monetary Fund (IMF, 2018), etc. Besides, it is necessary to closely monitor changes in the world economy, to both reduce the "import" of uncertainty due to our economy's high openness level, which was up to $203 \%$ in 2018 , and quickly identify the "broken links" in economic relations between countries, such as the US-China trade war, to develop replacement enterprises. Fast and strongly divert business direction, to cope with new changes, such as the emergence of specialized robots to replace simple labor, the 3D printing technology to replace processing and assembly, minimizing the losses of businesses.

\section{Things Vietnam should ponder when viewed from the Korean case}

Vietnam should reflect on the development case of Korea, because it is also a country with a small area, high population density, and located on a peninsula with a long maritime boundary, convenient for sea transportation. Both countries have about 12 years of stagnant economy after the war, and many years of development while the country was divided. Both have many similarities in culture, customs, way of life and way of thinking: both countries are influenced by Confucianism, Buddhism, and especially among the seven main families of Korea, the Lee family are of Vietnamese descent. In the 1960s, Korea was in such a difficult situation that President Moon Jai-in once said: "The Korean economy has survived thanks to the dedication and sacrifices of soldiers 
participating in the Vietnam War" (Wikipedia). At that time, Korea relied on aid and money from the US that were expensed for South Korean soldiers fighting in Vietnam, while its average income is low and belonging to the world's poorest country group.

Table 13. A comparison between Korea and Vietnam (unit of average income: USD)

\begin{tabular}{|c|c|c|c|c|c|c|c|c|}
\hline & \multirow{3}{*}{$\begin{array}{l}\text { Period of } \\
\text { hardships }\end{array}$} & \multirow{2}{*}{\multicolumn{2}{|c|}{$\begin{array}{l}\text { Most difficult } \\
\text { period }\end{array}$}} & \multirow{2}{*}{\multicolumn{2}{|c|}{$\begin{array}{l}31 \text { years after } \\
\text { reform }\end{array}$}} & \multicolumn{3}{|c|}{2017} \\
\hline & & & & & & \multirow{2}{*}{$\begin{array}{l}\text { Population } \\
\text { (thousand } \\
\text { people) }\end{array}$} & \multirow{2}{*}{$\begin{array}{l}\text { Populati- } \\
\text { on density }\end{array}$} & \multirow{2}{*}{$\begin{array}{l}\text { GDP } \\
\text { (billion } \\
\text { USD) }\end{array}$} \\
\hline & & Year & $\begin{array}{l}\text { Average } \\
\text { income }\end{array}$ & Year & $\begin{array}{l}\text { Average } \\
\text { income }\end{array}$ & & & \\
\hline Korea & 1953-1964 & 1963 & 120 & 1995 & 11,600 & $94,985.5$ & 519 & 1,531 \\
\hline Vietnam & $1975-1986$ & 1991 & 110 & 2017 & 2,160 & $50,990.3$ & 305 & 223 \\
\hline
\end{tabular}

Source: Wikipedia and WB

Even with a low starting point, poor resources, and is still in a state of war, but by 2015 , South Korea has had the 11th largest GDP in the world, which is more than Russia and Australia. The determinant of its success lies in that Korea was straightforward immediately, drastically quash any actions that were of arbitrary and antidemocratic nature, with a view that the country is more important than personal interests, forcing all international students to return home to serve, and applying "military discipline" and dictatorship nationwide. Even when new in power, Park Chung Hee has already executed 24 corrupt officials and businessmen, persecuted and "shoot anyone who stole from the public even only one dollar". Korea uses determination to build a nation of their own, and a unique national identity (Yergin and Stanislaw, 2006, p. 296), to shape the face of future Korean economy and society. But Korea's economic success also lies in some factors that Vietnam needs to ponder deeper, such as: (i) Saving, concentrating, and gathering all resources for developing the economy and enterprises. In the hard early days, the tight fiscal policy was applied from the President to the people. People worked hard (12-14 hours a day), skipped one meal every week, no imported tobacco, no coffee, in the belief that: "within 10 years, we will be the leading economy in East Asia, and after 20 years, we will become the world's economic power." (ii) Develop the country based on private Chaebol (large companies that control several industries), in the style of "Korea Inc." (a Korean company), such as Hyundai, Samsung, favoring exports. They believed that it was impossible to integrate into the international economy with small-scale enterprises and weak brands, so everyone joined force to turn private corporations into national brands. Through close relationships with business people, they focused on improving weaknesses, renovating management and operation structures to increase the competitiveness of businesses. (iii) Focus on attracting FDI to develop, but maintain strong and definitive orientation. In order to stop the misery of the people, Korea did not hesitate to lose face to mimic Japan and Singapore, attracting FDI wisely, promoting economic development. Not only creating "Miracle of the Han River", but Korea is also a leading country in developing an eco-friendly economy, is recognized as the Green Growth Power... (iv) Focus on SME development; since 1966, Korea has enacted the SME Law, bringing SME support into the Constitution; in the 1980s, they promulgated the Enterprise Promotion Law. This law designates that some industries and some products in these industries as auxiliary products, which require large enterprises to buy them from outside rather than produce them themselves (Nguyen The Binh, 2013). Thanks to that, numerous MSE are reaching out to the world along with the big corporations; Korea always pressures its businesses to innovate, even when successful, and is the first country to establish SME and Entrepreneur Ministry. (v) Resolutely improve the efficiency and discipline of the country's system, rectifying the bureaucratic delay of civil servants by an "iron hand", when the President often uses helicopters to suddenly comes to inspect directly construction sites. Every year at the beginning of the year, the President held a meeting with the ministers to review last year's promises - "one by one", anyone fulfilling less than $80 \%$ of them would be removed (Le Quoc Anh, 2017b). South Korea is also a rare country that has executed the former President, as well as imprison a current President for many years of corruption...

\section{Looking back and warning from China's economic and business development}

In the countries that resolutely develop socialism, Vietnam and China are neighboring countries, having many similarities in culture due to the fact that Vietnam once suffered a thousand years of Chinese domination. Of the 128 family names in Vietnam, there are many names, as well as many beliefs, customs and conceptions that are imported or have a close relationship with China. Currently, apart from having a dual political system and under the sole leadership of the Communist Party, the two countries also pursue two orientations of socialism. Both countries had about 30 years of developing a centrally planned Soviet-style economy, and there were many Chinese experts working as advisers for Vietnam. After years of economic turmoil, the two countries conducted economic reforms, shifted to a more market-oriented mixed economy, under the leadership of the Communist Party. Many ineffective state-owned enterprises were restructured; co-operatives and collective farms were dissolved or transformed, the land was allocated to households to manage... However, the most remarkable point was that many of the big changes in Vietnam were often a "copy" of China's previous changes, with a lag of about 10 years. It is of great practical significance to recognize, to use practice, as well as the disability of the Chinese economy, to 
revise and alert related activities in Vietnam.

Looking back at the development of the economy in general and of the businesses in particular in China, the following major points can be made: (i) The theories and methods that China used in the first 20 years (1949-1978) about building socialism was problematic, leading to the Chinese economy gradually exhausted. After only 10 years of implementation, China fell into the famine of "Three Bitter Years" 1959-1961 during the Great Leap Forward, causing 43 million deaths (Nguyen Minh Tri, 2015). Production stagnated, after 20 years the average income of people increased by 4 yuan only, foreign currency savings in 1978 was less than 0.2 USD per person (Ngo Hieu Ba, 2010, p.15). (ii) Innovation thinking methods, implementing "opening-up" helped China have an average growth of $9.7 \%$ per year in the period of 1980-2015 (Duong Tien Dung, 2019), which is a great lesson about successful development by attracting FDI, especially in the period 1978-2008. After 30 years, China became the second superpower in the world, with huge foreign currency savings in 2015 of 38,000 billion USD, number one in the world, but what was the economic drive? The argument "Black cats, white cats" helped promote the creativity of many party members' businesses significantly, but much conflicted to the Communist ideology that has been deeply rooted for decades (Friedman, 2006, p. 576). (iii) Still those people, but there were stagnant economic periods and periods whose growth was over 13\% per year. Hence is it possible that the change of mechanism from "communal" to "autonomic" is the biggest driving force of the majority? So are the notions of "exploitation", "bird and cage", "people at the bottom of society" (Ngo Hieu Ba, 2010, p. 30-35) a barrier, causing injustice, impractical, should be removed? Therefore, many old perceptions should be liberated, should not be prolonged, biased, asynchronous, and the "liberation" of thinking should be done naturally, cannot be forced. (iv) Chinese styled socialist economy is a market economy based on private property ownership, distorted because the state still holds strategic "pillars." The lack of a solid basis in the growth model, along with the "sugarcoating" of media and the obsession with empty achievement of the leadership brought economics into the development of risk accumulation. We should be skeptical with growth figures, such as those of the Shanghai stock market and Shenzhen in 1996, because they were not real, due to floating, and rudimentary controls (Friedman, 2005, p. 305), leading to many corporations sinking into "mountain of debt". (v) The reforms were prevented by barriers by economic institutions so it could not reach a full market economy; limited by political institutions so it could not proceed synchronously, causing many consequences. The most serious was corruption when a series of senior officials also "violated serious disciplines and laws"; only in 2015, 300,000 officials were prosecuted (Hai Anh, 2016). The unsupervised decentralization was exploited for personal benefits of the executives, causing racing investment, causing the debt of local government to increase rapidly, in 2015 to 18,000 billion yuan, equal to $1 / 3$ of GDP (Bao Nhu, 2015). (vi) Low labor cost and relatively low infrastructure cost, and the business acumen of the Chinese help China become number one in the world in manufacturing, becoming "the world's factory". But China needs a lot of energy, since 2010 it has become the world's largest energy consumer, over $70 \%$ of its energy needs are based on coal. So the environmental problem is becoming more serious, almost reaching an alarming level in big cities, deepening the macroeconomic risks, placing the economy on the "time bomb" (Hoang Nam, 2016). (vii) By the end of October 2018, China's Financial Stability Committee had to meet 10 times for "thematic" meetings within 2 months to discuss urgent economic and trade issues. Trade wars with the US add to the complexity, causing imports to plummet in 12/2018; At the beginning of 2019, the Shanghai stock market fell more than a quarter from the peak in 2018. Much bad news about bad debt, bankruptcy, showed that the economy is in a deep recession, creating a "Chinese-styled crisis" (Minh Duc, 2019), not easily overcome. (viii) The people feel insecure, although, since 2000, China has completed industrialization, but due to the strategy of "keep big, skip small" (Ngo Hieu Ba, 2010, p.107) makes the value of "representative for the basic concerns of the majority of Chinese people" (Yergin and Stanislaw, 2006, p. 390) fell. They have to pay up to 47 taxes, to make the gap between the rich and the poor increase sharply, the number of poor people according to the Chinese poverty line is about 100 million, mainly in rural areas. The yuan was abruptly lowered in 2015 , reducing welfare, creating a "rich country with poor people" peculiar, creating conflicts in society, causing growth to become exhausted (Acemoglu and Robinson, 2012, p. 562). (ix) The impractical mindset of the leadership through uneven "openingup" in the political-economic system is pushing Chinese society into a conflict of internal interests. China's rapid economic growth has created serious consumption inflation, so great pressure that on January 16, 2019, the Central Bank of China must pump about $\$ 83$ billion into the banking system. Intervening to prevent banks from collapsing, making the crisis long, persistent, but devastation and consequences are not inferior to major crises (Trung Men, 2019). (x) National governance's shortsightedness brings many immediate benefits but makes China pay dearly in the long-term international integration environment. China is the source of $70 \%$ of fake goods confiscated worldwide in the years 2008-2010, with a total value of over 17 billion USD (Wikipedia). The risk of losing prestige with China is higher, as many countries boycott Huawei for suspecting "left-over components", canceling the project related to the "One Belt, One Road" initiative because of suspicion of China setting debt traps to increase dependence on China... 


\section{Very difficult, but believing in success and full of hope...}

It is hard to deny: the development of enterprises in Vietnam is urgent, but difficult in the current context because, besides the obstacles presented above, there are many indirect obstacles. Typically: (i) Because the socialist orientation is still "fumbling, unprecedented" (Bui Tat Thang, cited by Huyen Tram, 2015), but Vietnam always worries about "deviation", so it is difficult for policy making, missing many development opportunities. Often "exaggerate" achievements, sugarcoat drawbacks, lack of thorough analysis and evaluation, create "policy illusion" mindset (Tran Dinh Thien, cited by Phuong Ha, 2015), making investors confused, insecure, distrust. (ii) Lack of resources to handle the consequences of the past, because of the lack of money to support streamlining staff, complementing the weak and lacking stages, not being able to raise wages so that civil servants can live on wages. The need to tolerate "light" corruption makes it difficult to filter and streamline the actual apparatus, significantly disabling good policies, preventing them from being implemented thoroughly. (iii) Policy thinking is not good, there is little quantitative analysis in forecasting analysis, but if there is any then it is not high quality because the statistical data is still limited and "not accurate" (Vu Viet Ngoan, cited by Phuong Ha, 2015). In the technological age, things change minute by minute, but many conclusions are sluggish, having to push through many levels of management, leading to a lack of timeliness in international competition. (iv) It is difficult to arrange the apparatus between entangling power and interests, due to the structure and functions that have remained unchanged for decades, thus forming interest groups in many sectors and fields. It is difficult to eliminate, it is difficult to distinguish, evaluate, handle conflicts between "principles and moral" and "expertise, knowledge, and profession", between personal interests and common interests, when corruption is deep and widespread in the apparatus ( $\mathrm{Vu}$ Mao, cited by Trinh Phuc, 2016). (v) Vietnam integrates but has criteria and standards different from the majority of countries, including similar countries or highly rated countries in the world. This, especially when Vietnam is in the "inferior" position has caused more difficulties for Vietnamese businesses, making them more and more tied to the cramped framework, distorting the market and reducing the competitiveness of enterprise...

However, it is not the reason that the development of enterprises in Vietnam will be less probable, less promising and riskier, but we still have many reasons to believe in success. For one thing, the Party's perception of business and the need for business development has changed, the importance has increased, though there has not been a specialized Resolution on this area. However, the Resolution No. 10-NQ/TW of the 5th meeting of the Central Committee of the Communist Party XII on private economic development has placed strategic importance on the enterprise. Secondly, after many years of misery in the cycle of managing and coping, especially in the period of 2007-2013, enterprises are on the verge of collapsing due to "lack of capital" and "expensive capital" of regular double-digit interest rate. So far, the Government has strongly shifted to creating-developing, placing businesses in the center of development; the stock market has grown significantly, the market capitalization reached $75 \%$ of GDP, accounting for $14 \%$ of total capital supply. Thirdly, the activities of the Prime Minister's Advisory Groups after re-establishment gave many important results, especially of the Economic Advisory Group, so that the policy quality is getting higher and higher. It not only helps the country's economy have a proper orientation, develops in the right place and with the right force, but also reduces the allocation of resources to unrealistic goals, preventing unnecessary business breakdowns. Fourthly, the spirit of constantly striving and overcoming difficulties of the entire population, especially of intellectuals and Vietnamese businessmen when the country encounters difficulty, because of the nation's future. A series of national and international conferences were organized, many enthusiastic and responsible proposals were made, for the whole nation's wisdom to be gathered and served for the overall development goals according to the related visions. Fifthly, support and encouragement from international organizations, especially from WB, IMF, ADB, or from partners in FTAs, foreign business associations in Vietnam, such as EuroCham, AmCham. Besides, it is the cooperation and contribution of nearly 5 million patriots from all over the world, of tens of thousands of students, trainees, overseas students who are diligently approaching and accumulating knowledge and experience of other countries, looking forward to contributing to developing the country...

Not only that, the possibility for success in business development in Vietnam is increasing, because many changes in politics, economy, society, as well as life, are in favor of development needs. Firstly, the Party is stepping up the process of building and regulating the Party, strengthening the attraction of talents, promoting the fight against corruption without forbidden zones, preventing manifestations of self-transformation and selfprogression... As a result, human resources are promoted, deteriorating elements are eliminated, hoping to create a major change in the dynamics of the elite of the production force. Secondly, this tenure Government is increasingly asserting the role of creating-developing, reinforcing the belief in directing and administration, and well fulfilling the principle of "Accompanying and supporting enterprises". Decree No. 57/2018/ND-CP dated April 17, 2018, on amending and supplementing incentives and supports for enterprises along with guidelines in Circular No. 04/2018/TT-BKHDT dated December 6, 2018, hope to open a business development climax in the coming years. Third, the reversal in direction but not lower the bottom in growth in 2017-2018, showing that the impetus for reform is becoming effective, overwhelming the resistance. These achievements are a stepping stone, together with the efforts of the Party and the Government, the response of investors, and the contribution of the 
entire population, hopefully, the business development targets for 2020, 2025 and 2030 though difficult but will come true.

Table 14. Growth in the bottom line of 10 -year periods of Vietnam economy (\%)

\begin{tabular}{|c|c|c|c|c|c|c|c|c|c|c|}
\hline "Near bottom" & 1970 & .. & 1980 & $-1,4$ & 1990 & 5,101 & 2000 & 6,787 & 2010 & 6,423 \\
\hline & 1971 & .. & 1981 & 2,3 & 1991 & 5,961 & 2001 & 6,193 & 2011 & 6,240 \\
\hline & 1972 & .. & 1982 & 8,8 & 1992 & 8,646 & 2002 & 6,321 & 2012 & 5,247 \\
\hline & 1973 & .. & 1983 & 7,2 & 1993 & 8,073 & 2003 & 6,899 & 2013 & 5,422 \\
\hline & 1974 & .. & 1984 & 8,3 & 1994 & 8,839 & 2004 & 7,536 & 2014 & 5,984 \\
\hline "Peak" & 1975 & .. & 1985 & 3,806 & 1995 & 9,540 & 2005 & 7,547 & 2015 & 6,679 \\
\hline & 1976 & .. & 1986 & 2,789 & 1996 & 9,340 & 2006 & 6,978 & 2016 & 6,211 \\
\hline & 1977 & 2,8 & 1987 & 3,583 & 1997 & 8,152 & 2007 & 7,130 & 2017 & 6,812 \\
\hline & 1978 & 2,3 & 1988 & 5,135 & 1998 & 5,764 & 2008 & 5,662 & 2018 & 7,080 \\
\hline "Bottom" & 1979 & $-2,0$ & 1989 & 7,365 & 1999 & 4,774 & 2009 & 5,398 & 2019 & .. \\
\hline
\end{tabular}

Source: Data from 1977-1984 according to Vietnam Economic Times, from 1985-2017 according to WB

Fourth, FIR will be the key to help Vietnam create a breakthrough in enterprise development, thanks to a large number of young human resources, high level of education, desire to learn and need for progress. This hope is greater, as the Government of Vietnam is making efforts to build human resources 4.0, ecosystem 4.0 and culture 4.0; at the same time, the World Economic Forum will build an FIR center in Vietnam in 2019 (Hoang Vu, 2018). Fifth, the current changes in Vietnam are receiving recognition and appreciation from the great experts and key financial institutions and organizations in the world. Many articles on the WEF website, in Economist, Forbes, Bloomberg - have a positive view of Vietnam, using the words "miraculous", "exemplary", "outstanding" etc. (Tran Quang Vinh, 2019) promising to bring to Vietnam many great FDI sources to support development. Besides, the most important thing is that Vietnam has so far been fully and comprehensively aware of the enterprises and the necessity of business development. Relevant issues have been identified, analyzed at different angles, while the Party's political determination, the Government's efforts to implement are very high, so the expectation of success is greater... Therefore, if Vietnam promotes its achievements, to overcome and limit reasonable obstacles and weaknesses, to make a breakthrough developing business on a solid basis, meeting practical needs. If we innovate thinking and ways of developing business areas, based on open directions, then the practice on the stance of "no discoloration, no deviation", will not be difficult. If we apply Korea's experience more deeply and are more alert to Chinese practices, then the difficult development of the enterprise is still highly probable to success and full of hope...

\section{References}

Acemoglu, D. and Robinson, J. (2012), Why Nations Fail: The Origins of Power, Prosperity, and Poverty, translation by Nguyen Thi Kim Chi, Tre Publishing House, Hochiminh city.

An Lan (2016), What does EuroCham propose to Vietnamese businesses to improve their competitiveness? Visited on January 31, 2019, from: <https://vietnamfinance.vn/eurocham-hien-ke-gi-cho-doanh-nghiep-viet-nangsuc-canh-tranh-20170616140604587.htm>.

Bao Anh (2011), Fasting for... public investment? Visited on January 10, 2019, from $<$ http://vneconomy.vn/thoisu/nhin-an-de-dau-tu-cong-20111027074527114.htm>

Bao Nhu (2015), The risk of a debt crisis in China, visited on February 06, 2019, from <http://cafef.vn/tai-chinhquoc-te/nguy-co-khung-hoang-no-o-trung-quoc-20150707085606026.chn>

Bui Trinh (2014), Where does GDP go? Visited on January 21, 2019, from <http://vneconomy.vn/thoi-su/gdpchay-di-dau-20140206031427536.htm>

Cam Thuy (2014), Lawyer Nguyen Tran Bat: "Our economy is an economy that has to be redone from scratch", visited on January 24, 2019, from <http://cafef.vn/vi-mo-dau-tu/luat-su-nguyen-tran-bat-nen-kinh-te-cuachung-ta-la-nen-kinh-te-phai-lam-lai-tu-dau-2014101209381606017.chn>

Communist Party of Vietnam (2007), Full Party Documents, National Political Publishing House, vol. 53

Dapice et al (2006), The Lessons of East and Southeast Asia and Vietnam's Future, visited on January 18, 2019, from <http://www.vn.undp.org/content/vietnam/vi/home/library/poverty/choosing-success--the-lessons-ofeast-and-southeast-asia-and-vie.html>

Dang Phong (2012), Vietnam's economic thinking 1975 - 1989, Tri Thuc Publishing House, Hanoi.

Duong Tien Dung (2019), Restructuring the state budget expenditure in some countries and lessons for Vietnam, visited on February 04, 2019, from < http://tapchitaichinh.vn/su-kien-noi-bat/co-cau-lai-chi-ngan-sach-nhanuoc-o-mot-so-quoc-gia-va-bai-hoc-cho-viet-nam-302828.html $>$

Friedman, T.L (2005), The Lexus and The Olive Tree, translation by Le Minh, Khoa hoc Xa hoi Publishing House, Ho Chi Minh City. 
Friedman, T.L (2006), The Flat World, translation by Nguyen Quang A et al, Tre Publishing House, Ho Chi Minh City.

Hai Anh (2016), 300,000 Chinese officials were prosecuted in 2015, visited on February 05, 2018, from $<$ http://news.zing.vn/300000-quan-tham-trung-quoc-bi-xu-ly-trong-nam-2015-post632088.html>

Hieu Cong (2018), 'Super small, small and medium' entrepreneurs in front of big seas, visited on January 10, 2019, from < https://baomoi.com/nhung-doanh-nhan-sieu-nho-nho-va-vua-truoc-bien-lon/c/28136946.epi>

Hoang Nam (2016), China's "time bomb" threatens a new global economic crisis, visited on February 08, 2018, from <http://cafebiz.vn/qua-bom-no-cham-cua-trung-quoc-dang-de-doa-mot-cuoc-khung-hoang-kinh-tetoan-cau-moi-20160517162917977.chn>

Hoang Thi Nang Hong (2013), Current situation of public debt and public debt management in Vietnam, visited on January 05, 2019, from <http://www.tapchitaichinh.vn/Nghien-cuu-dieu-tra/Thuc-trang-no-cong-vaquan-ly-no-cong-o-Viet-Nam/31983.tctc $>$

Hoang Vu (2018), WEF opens a Center for FIR in Vietnam within the next year, visited on January 18, 2019, from $<$ http://www.xahoithongtin.com.vn/vien-thong-cntt/201809/wef-mo-trung-tam-ve-cmcn-40-tai-viet-namtrong-nam-toi-614208/>

Huyen Trang (2018), Cutting down business conditions: still debating at the last minute, visited on January 28 , 2019, from <http://enternews.vn/cat-giam-dieu-kien-kinh-doanh-lan-can-tan-phut-cuoi-139924.html>

Huyen Tram (2019), Stock 2019 will depend on what "variable"? Visited on February 12, 2019, from $<$ https://bizlive.vn/chung-khoan/chung-khoan-2019-se-phu-thuoc-vao-nhung-bien-nao-3487998.html >

Kenichi Ohno (2010), Avoiding the Middle Income Trap: Renovating Industrial Policy Formulation in Vietnam, Overcoming the middle-income trap: Opportunities and challenges for Vietnam”, Giao Thong Van Tai Publishing House.

Le Kien Thanh (2017), Dr. Le Kien Thanh: After 30 years, reflect on the second reform, visited on January 12, 2019, from <http://antgct.cand.com.vn/So-tay/Sau-30-nam-nghi-ve-cuoc-doi-moi-lan-thu-hai-428419/>

Le Quoc Anh (2017a), New generation FTAs with Vietnam's industrial development issue, Proceedings of the International Scientific Conference on "Vietnam's economic development in the process of international integration", Hanoi Publishing House, vol. 1, p. 398-410.

Le Quoc Anh (2017b), Promoting the role of the Government to create and solve the "false step" of TPP for Vietnamese enterprises, Proceedings of the National Scientific Conference "Prospects for Vietnam's economic development and the role of the Government to create in improving institutions and business environment", Publishing House of National Economics University, Hanoi, page 311-330.

Le Quoc Anh et al. (2018), Business development in Vietnam: Current situation and solutions, Economic Management Journal of Central Institute for Economic Management, No. 89 July + August/2018, p. 36-44.

Le Quoc Anh \& Le Thi Tram Anh (2017), Innovating the Machinery of Government to support the International Economic Integration of enterprises, Proceedings of conference: "Economic and business issues in Vietnam in the context of international integration" (EIIB-2017), p. 149-162.

Le Quoc Anh \& Le Thi Tram Anh (2018a), Economic development in lower middle-income countries in this day and age, through practical study in Vietnam, Proceedings of Conference "Contemporary Issues in Economics, Administration and Business" (1st CIEMB 2018), p. 1029-1047.

Le Quoc Anh \& Le Thi Tram Anh (2018b), New generation FTAs with Vietnam's business development issues, Proceedings of the International Conference on "Trade and Distribution" - CODI 2018, Nong Nghiep Publishing House, page 1028-1038.

Le Quoc Anh \& Le Thi Tram Anh (2018c), Sustainable business and development of medium enterprises in the context of the fourth industrial revolution, Proceedings of International scientific conference "Sustainable business in the context of the fourth industrial revolution", Publishing House of National Economics University, p. 394-409.

Le Quoc Anh \& Le Thi Tram Anh (2018d), Vietnam private enterprise in 2018: Many difficulties but much hope, Proceedings of the National Scientific Conference "Vietnam's economy 2017 and prospects for 2018", Publishing House of National Economics University, p. 197-210.

Le Quoc Anh \& Tran Hoai Thanh (2018), Shifting economic structure to integrate into the fourth industrial revolution, Proceedings of International Scientific Conference "Forth Industrial revolution: Opportunities and challenges for Vietnam's economic development", Hanoi Publishing House, Vol 1, p. 577-589.

Minh Duc (2019), Is China in a financial crisis? Visited on February 09, 2019, from <https://news.zing.vn/trungquoc-dang-trong-khung-hoang-tai-chinh-post910915.html>

Ngo Hieu Ba (2010), Economic breakthrough in China (1978 - 2008), translation by Nguyen Thi Thu Hang, Ho Chi Minh City General Publishing House.

Ngoc Diep (2019), What is the Asian economy expecting in 2019? Visited on February 10, 2019, from $<$ http://thuonggiaonline.vn/kinh-te-chau-a-cho-doi-gi-trong-nam-2019-21365.htm>

Nguyen Hoai (2016), Mr. Vo Tri Thanh: Enterprises are falling into the trend of seclusion, visited on January 08, 
2019, from <http://infonet.vn/ong-vo-tri-thanh-doanh-nghiep-dang-roi-vao-xu-huong-li-ti-hoapost192346.info>

Nguyen Hung (2017), Starting a creative innovating business: It is necessary to have policies for investors to see opportunities, visited on January 28, 2019, from <http://dantri.com.vn/khoa-hoc-cong-nghe/khoi-nghiep-doimoi-sang-tao-can-co-chinh-sach-de-nha-dau-tu-nhin-thay-co-hoi-20171114224426054.htm>

Nguyen Minh Tri (2015), Shuddering at the greatest famine in human history, visited on February 02, 2019, from $<$ https://www.ohay.tv/view/rung-minh-nhung-nan-doi-khung-khiep-nhat-lich-su-loai-nguoi/576629d9f1>

Nguyen The Binh (2013), International experience on policies to support small and medium enterprises to develop and lessons for Vietnam, visited on February 18, 2019, from $<$ http://www.vjol.info/index.php/kttc/article/viewFile/12398/11311>

Nhue Man (2018), WB suggested 2 directions to help Vietnam get rid of the manual processing industry, visited on February 18, 2019, from <https://baomoi.com/wb-goi-y-2-huong-di-giup-viet-nam-thoat-khoi-nen-sanxuat-gia-cong/c/23217455.epi>

Phuong Ha (2015), Beware of "illusional" economic thinking, visited on February 14, 2019, from $<$ http://danviet.vn/kinh-te/canh-giac-voi-tu-duy-kinh-te-ao-tuong-666966.html >

Shlomo Maital (2015), Economics for entrepreneurs, translation of Anh Tu, Lao dong - Xa hoi Publishing House, Hanoi.

Vietnam Economic Times (2006), Vietnam's economy 61 years after the Revolution, visited on January 05, 2019, from <http://vietbao.vn/Kinh-te/Kinh-te-Viet-Nam-61-nam-sau-Cach-mang/55122137/88/>

Thai Phuong (2018), Private enterprises do not want to grow or cannot grow? Visited on January 11, 2019, from $<$ https://phapluatxahoi.vn/doanh-nghiep-tu-nhan-khong-muon-lon-hay-khong-the-lon-128254.html $>$

Tran Dinh Thien (2011), Slices of Vietnamese economy structure, visited on January 26, 2019, from $<$ https://vietnamnet.vn/vn/thoi-su/lat-cat-co-cau-nen-kinh-te-viet-41378.html>

Tran Quang Vinh (2019), Prerequisite for Vietnam to "continue writing the song of triumph", visited on February 18, 2019, from <https://baotintuc.vn/thoi-su/tien-de-de-viet-nam-khai-hoan-viet-tiep-bai-ca20190207072748914.htm>

Thuy Khanh (2018), "Assoc. Dr. Nguyen Duc Thanh: Vietnam should devalue the dong by 2-3\%, visited on February 08, 2019, from <https://vietnamfinance.vn/pgsts-nguyen-duc-thanh-viet-nam-nen-pha-gia-tiendong-tu-2-3-20180504224209689.htm>

Trinh Phuc (2017), Mr. Vu Mao: There are many loopholes for officials to exploit leading to serious corruption, visited on February 16, 2019, from < http://giaoduc.net.vn/Xa-hoi/Ong-Vu-Mao-Con-nhieu-so-ho-de-can-bolong-quyen-dan-den-tham-nhung-nghiem-trong-post174030.gd>

Trung Men (2019), How is the Chinese-style crisis different from the Western crisis? Visited on February 10, 2019, from <https://bizlive.vn/kinh-doanh-quoc-te/cuoc-khung-hoang-kieu-trung-quoc-khac-khung-hoangphuong-tay-nhu-the-nao-3490098.html>

Tu Giang (2015), "We only have two choices, opening up or die", visited on January 30, 2019, from $<$ http://fica.vn/dong-chay-von/-chung-ta-chi-con-hai-lua-chon-mo-cua-hay-la-chet--33128.html>

Tu Giang (2018), "Basket boats" and a paradox named private business, visited on January 28, 2019, from $<$ http://ndh.vn/doan-thuyen-thung-va-nghich-ly-mang-ten-doanh-nghiep-tu-nhan20180807102941468p145c151.news>

VCCI (Vietnam Chamber of Commerce and Industry, 2018), Vietnam Business Annual Report 2017/2018, Thong tin va Truyen thong Publishing House.

Vu Quang Viet (2018), Economic FDI dependency - implications, visited on January 15, 2019, from $<$ https://www.thesaigontimes.vn/275056/kinh-te-phu-thuoc-fdi--nhung-he-luy.html $>$

$\mathrm{Vu}$ Thanh $\mathrm{Tu}$ Anh (2018), The FDI paradox, visited on January 16, 2019, from $<$ https://www.thesaigontimes.vn/td/275054/nghich-ly-fdi.html $>$

Xuan Dan (2019), The first meeting the Party's Subcommittee of Document of the XIII Congress, visited on January 03, 2019, from <https://vov.vn/chinh-tri/dang/phien-hop-thu-nhat-tieu-ban-van-kien-dai-hoi-xiii-cua-dang861458.vov>

WB (2016), Vietnam: Enhancing the competitiveness and linkage of small and medium enterprises, Lessons learned in the country and internationally, visited on February 15, 2019, from $<$ file://C:/Users/Administrator/Desktop/T\%C4\%83ng\%20C\%C6\%B0\%E1\%BB\%9Dng\%20N\%C4\%83ng $\% 201 \%$ E1\%BB $\%$ B1c\%20C\%E1\%BA\%A1nh\%20cho\%20SME.pdf $>$

Wikipedia (...). Korean, Chinese, country lists...

Yergin, D. and Stanislaw, J. (2006), The commanding heights: the battle for the world economy, translation by World Knowledge Quintet Bookcase, Tri Thuc Publishing House, Hanoi 